UDC $612.35: 577.23$

doi: https://doi.org/10.15407/ubj92.04.045

\title{
TiO $_{2}$ HEPATOTOXICITY UNDER LONG-TERM ADMINISTRATION TO RATS
}

\author{
O. V. TSYMBALYUK, S. P. VESELSKY, A. M. NAUMENKO, T. L. DAVYDOVSKA, \\ I. S. VOITESHENKO, I. I. CHYZH, V. A. SKRYSHEVSKY
}

Institute of High Technologies, Taras Shevchenko National University of Kyiv, Ukraine; e-mail: otsymbal@bigmir.net

Received: 30 March 2020; Accepted: 15 May 2020

Titanium dioxide $\left(\mathrm{TiO}_{2}\right)$ powder which is used as a white dye was considered to be an inert material for a long time despite its accumulation in liver tissues after penetration into organism. The aim of the study was to estimate biochemical markers of liver functioning in blood plasma and ATPase activity of erythrocyte plasma membrane under the oral administration of $\mathrm{TiO}_{2}$ nanoparticles suspension ( $0.1 \mathrm{mg} / \mathrm{kg}$, daily) to Wistar rats for 30 and 100 days. A significant increase of alanine aminotransferase and aspartate aminotransferase activity as well as of direct, indirect and bound bilirubin content, a decrease of connjugated (taurocholic, taurochenodeoxycholic, taurodeoxycholic, glycocholic, glycochenodeoxycholic, and glycodeoxycholic) and free (glycodeoxycholic and deoxycholic) bile acids concentration with concomitant increase of free cholic acid concentration in blood plasma of rats under $\mathrm{TiO}_{2}$ administration were revealed, indicating a significant impairment of pigment exchange in the liver of rats. Under $\mathrm{TiO}_{2}$ administration a substantial inhibition of erythrocyte plasma membrane $\mathrm{Mg}^{2+}$-dependent ouabain-sensitive $\mathrm{Na}^{+}, \mathrm{K}^{+}$-ATPase and ouabain-insensitive ATPase was observed. These results presume the disturbance of transplasmalema ion-transporting processes and cells ionic homeostasis induced by $\mathrm{TiO}_{2}$.

Keywords: $\mathrm{TiO}_{2}$ nanoparticles, alanine aminotransferase, aspartate aminotransferase, bilirubin, bile acids, plasma membrane ATPase activities.

$\mathrm{N}$ anomaterials are artificially synthesized materials, containing at least $50 \%$ particles of 1-100 $\mathrm{nm}$ in at least one projection. Modern industrial technologies envisage extensive application of nanomaterials, as the approximation of a system to the electron coherence length leads to significant changes in its properties, including enhanced stability and catalytic activity $[1,2]$. For instance, titanium dioxide $\left(\mathrm{TiO}_{2}\right)$ powder is used as a white dye (for instance, to dye paper, paints, food, medical and cosmetic products) and is manufactured in the amount, exceeding $70 \%$ from the total amount of pigments [3, 4]. Food additive E171 is a suspension of micro- and nanoparticles of $\mathrm{TiO}_{2}$ with the diameter within $30-400 \mathrm{~nm}$, and a third of its mass is composed of particles, sized $<100 \mathrm{~nm}$ [5]. Nanoscale $\mathrm{TiO}_{2}$ may be in the form of crystal structures of rutile, anatase, and brookite, though the latter is almost not found in industrial samples [6].

$\mathrm{TiO}_{2}$ has been considered inert material for a long time. However, a considerable amount of accumulated data proves the ability of this material to have damaging effect on the cells of different tissues and organs [7-10]. For instance, a key cellular mechanism of nano- $\mathrm{TiO}_{2}$ effect is generation of reactive oxygen intermediates and active forms of nitrogen, and, as a result, oxidative stress of the cell. Nano- $\mathrm{TiO}_{2}$ increases the concentration of reactive oxygen intermediates in several ways: firstly, via depletion of molecules of the antioxidant protection of cells; secondly, via high superficial activity of nanoparticles, conditioned by oxygen vacancies on their surface. Nanoparticles of $\mathrm{TiO}_{2}$ in the form of anatase are relatively more active [11].

(C) 2020 Tsymbalyuk O. V. et al. This is an open-access article distributed under the terms of the Creative Commons Attribution License, which permits unrestricted use, distribution, and reproduction in any medium, provided the original author and source are credited. 
Nano- $\mathrm{TiO}_{2}$ penetrates the organism in several ways: inhaling, intragastric, transdermal; these particles may also occur in the milieu interieur due to medical manipulations, for instance, via injection of medical preparations and during the destruction of bioimplants, based on titanium dioxide [12]. However, the most common way of organism exposure to this nanomaterial is its penetration via the intestinal barrier. In addition, the experiments on chronic effects of $\mathrm{TiO}_{2}$ in vivo demonstrated that, after penetrating the organism, this nanomaterial gets accumulated in liver tissues in considerable amounts $[8,13,14]$. It is known that venous blood from the digestive system goes to the portal system of the liver, therefore, we performed the analysis of biochemical markers of liver functioning and damage along with the enzymatic activity of preparations of rat erythrocyte plasma membrane under the effect of nano- $\mathrm{TiO}_{2}$ during intragastric administration in vivo.

\section{Materials and Methods}

The chronic effect of nanoscale $\mathrm{TiO}_{2}$ material was studied using female rats of Wistar line from the population of the vivarium of SI Institute of Pharmacology and Toxicology NMA of Ukraine. The rats were kept with standard diet and under standard conditions: temperature of $20 \pm 2{ }^{\circ} \mathrm{C}$, relative air humidity $50-70 \%$, light regime - light:darkness $=12: 12 \mathrm{~h}$.

The animals were randomly divided into 3 groups: group 1 - intact rats; group 2 - rats, oral administered the suspension of $\mathrm{TiO}_{2}$ nanoparticles, estimated as $0.1 \mathrm{mg} / \mathrm{kg}$, daily for 30 days; group 3 - rats, oral administered the suspension of $\mathrm{TiO}_{2}$ nanoparticles, estimated as $0.1 \mathrm{mg} / \mathrm{kg}$, daily for 100 days. The weight of animals was controlled every 4-6 days for adequate estimation of $\mathrm{TiO}_{2}$ amount.

Nanoparticles of $\mathrm{TiO}_{2}$ (PlasmaChem $\mathrm{GmbH}$, D-12489 Berlin, Germany) were used in the form of nanopowder (mixture of rutile and anatase in 1:4 ratio), the size of particles $(21 \pm 5) \mathrm{nm}$, the specific surface $-(50 \pm 10) \mathrm{m}^{2} / \mathrm{g}$; purity $>99.5 \%$, content of $\mathrm{Al}_{2} \mathrm{O}_{3}<0.3 \mathrm{wt} ; \mathrm{SiO}_{2}<0.2$ wt. $\mathrm{TiO}_{2}$ nanopowder was resuspended in water; the aggregates of $\mathrm{TiO}_{2}$ nanoparticles in the suspension were broken using the ultrasound.

The biochemical markers of damage and functional ability of the liver under long-term exposure of the organism to nanosize $\mathrm{TiO}_{2}$ were studied using the preparations of blood plasma and the suspension of rat erythrocyte plasma membranes. All the experiments using animals were conducted in ac- cordance to the legislation of Ukraine and norms of the European Union regarding humane treatment of laboratory animals.

Obtaining blood plasma. Blood with anticoagulant (heparin, 5,000 IU/ml) in blood:heparin ratio of 9:1 was centrifuged at $3,000 \mathrm{rpm}$ for $10 \mathrm{~min}$. Plasma was thoroughly isolated with a pipette and further kept for $12-24 \mathrm{~h}$ at $4{ }^{\circ} \mathrm{C}$ until used in the experiments of determining the activity of alanine aminotransferase (ALT) and aspartate aminotransferase (AST), bilirubin concentration and thymol test. The precipitation (blood corpuscles) was further used to obtain the preparations of erythrocyte plasma membranes.

Determining the activities of aspartate aminotransferase and alanin aminotransferase in blood plasma of rats was performed by the method of Reitman and Frankel using the kits, manufactured by R\&D enterprise Felicit-Diagnostika (Ukraine) [15].

Total and direct bilirubin in blood plasma were determined by the method of Jendrassik using the kits, manufactured by R\&D enterprise Felicit-Diagnostika (Ukraine) [16].

Thymol test was performed using thymol reagent from the kits, manufactured by R\&D enterprise Felicit-Diagnostika (Ukraine) [17].

Isolating and determining concentrations of free and conjugated bile acids from the blood of rats was performed by the method of S.P. Veselskyi [18]. Bile acids were extracted from the biological material at $\left(-10-0{ }^{\circ} \mathrm{C}\right)$ using the mixture of ethanol and acetone (1:3). Free and conjugated bile acids were chromatographically separated in the system, containing amyl acetic ester, toluene, butanol, acetic acid and water in the (3:1:1:3) ratio, which ensured simultaneous separation of free and conjugated biliary acids with unidimensional chromatography on standard Silufol plates. The content of each bile acid was quantitatively estimated after spraying chromatograms with 5\% solution of phosphatomolybdic acid in the mixture, containing ice-cold acetic acid, concentrated sulphuric acid and 50\% solution of trichloroacetic acid in 15:1:5 ratio.

Obtaining preparations of erythrocyte plasma membrane. The preparations of suspension of erythrocyte plasma membrane were obtained by slightly modified method of Dodge. Erythrocytes were washed thrice with a cooled solution of the following composition: $\mathrm{NaCl} 145 \mathrm{mM}$, Tris-HCl $20 \mathrm{mM}\left(\mathrm{pH} 7.6\right.$ at $20{ }^{\circ} \mathrm{C}$ ), each time precipitating the cells by centrifugation at 3,000 rpm for $10 \mathrm{~min}$. 
Erythrocyte membranes were obtained by hyposmotic hemolysis in the following solution: EDTA $10 \mathrm{mM}$, Tris- $\mathrm{HCl} 10 \mathrm{mM}\left(\mathrm{pH} 7.6\right.$ at $\left.20^{\circ} \mathrm{C}\right)$. For this purpose, one volume of washed erythrocytes was thoroughly mixed with 20 volumes of cooled $\left(4{ }^{\circ} \mathrm{C}\right)$ hemolytic medium and kept at the same temperature for $15 \mathrm{~min}$. The hemolysate was centrifuged at $18,000 \mathrm{rpm}$ for $15 \mathrm{~min}$. The precipitate (membranes) was washed thrice with 20 volumes of $10 \mathrm{mM}$ Tris$\mathrm{HCl}$ buffer ( $\mathrm{pH} 7.6$ at $\left.20^{\circ} \mathrm{C}\right)$. The preparations of plasma membranes were further kept for $12-24 \mathrm{~h}$ at $4{ }^{\circ} \mathrm{C}$ until used in the experiments to study the enzymatic activity: total $\mathrm{Mg}^{2+}, \mathrm{Na}^{+}, \mathrm{K}^{+}$-ATPase, basal $\mathrm{Mg}^{2+}$-ATPase and $\mathrm{Na}^{+}, \mathrm{K}^{+}$-ATPase. Protein concentration in the preparations of rat erythrocyte plasma membrane was determined by Lowry's method [19].

Determining total ATPase activity. Total $\mathrm{Mg}^{2+}, \mathrm{Na}^{+}, \mathrm{K}^{+}$-ATPase activity was determined at $37^{\circ} \mathrm{C}$ in the fraction of erythrocyte plasma membranes in the standard incubation medium (volume of $0.4 \mathrm{ml}$ ) of the following composition (in $\mathrm{mM}$ ): 1 ATP, $3 \mathrm{MgCl}_{2}, 125 \mathrm{NaCl}, 25 \mathrm{KCl}, 1$ EGTA, 20 Hepes-Tris-buffer ( $\mathrm{pH}$ 7.4), $1 \mathrm{NaN}_{3}$ (inhibitor of mitochondria ATPase) [20]. It was added $0.1 \mu \mathrm{M}$ thapsigargin (selective inhibitor of $\mathrm{Ca}^{2+}, \mathrm{Mg}^{2+}$-ATPase of endo(sarco)plasmatic reticulum) and $0.1 \%$ digitonin (factor of plasma membrane perforation). Protein amount in the membrane fraction of the sample was 20-30 $\mu \mathrm{g}$, the incubation lasted $4 \mathrm{~min}$.

The enzymatic reaction was initiated by the introduction of the aliquot $(20 \mu \mathrm{l})$ of plasma membrane suspension $\left(8^{\circ} \mathrm{C}\right)$ to the incubation medium, and terminated by the introduction of $1 \mathrm{ml}$ of $20 \%$ trichloroacetic acid $\left(\mathrm{pH} 4.3\right.$ at $\left.8{ }^{\circ} \mathrm{C}\right)$ to the incubation mixture.

The incubation medium, having a similar composition but lacking fragments of plasma membranes, served as control for non-enzymatic hydrolysis of ATP. Aqueous solution of the membranes served as control for the amount of endogenous $\mathrm{P}_{i}$ in the membrane preparation. Thus, total ATPase activity was calculated as the difference between the amount of $\mathrm{P}_{\mathrm{i}}$, formed in the incubation medium with and without plasma membranes. The allowance for the amount of endogenous $\mathrm{P}_{\mathrm{i}}$ in the membrane preparation was made. The amount of $\mathrm{P}_{\mathrm{i}}$ reaction product was determined by the method of W. Rathbun et V. Betlach [21].

Determining $\mathrm{Mg}^{2+}$-ATPase activity. Basal $\mathrm{Mg}^{2+}-$ ATPase activity was determined in the incubation medium, used for total ATPase activity, but in the presence of $1 \mathrm{mM}$ ouabain (selective inhibitor of $\mathrm{Na}^{+}, \mathrm{K}^{+}$-ATPase) [20].

Estimating $\mathrm{Na}^{+}, \mathrm{K}^{+}$-ATPase activity. Ouabain-sensitive $\mathrm{Na}^{+}, \mathrm{K}^{+}$-ATPase activity was calculated as the difference between the amount of total $\mathrm{Mg}^{2+}, \mathrm{Na}^{+}, \mathrm{K}^{+}$-ATPase and basal (ouabain-insensitive) $\mathrm{Mg}^{2+}$-ATPase activity [20].

Statistical analysis. Experimental data were processed by variation statistics methods using OriginPro 8 program. The samples were checked in terms of belonging to normally distributed general populations according to Shapiro-Wilk test. Parametric one-way ANOVA analysis was used to determine reliable differences between mean values of samplings; post-hoc comparison was made using Tukey test. In all cases the results were considered reliable on condition of the probability value $P$, under 5\% $(P<0.05)$. The results were presented as the mean \pm standard error of the mean value, $n$ - number of experiments.

\section{Results and Discussion}

Studying biochemical markers of rat liver functioning under chronic exposure to nanosize $\mathrm{TiO}_{2}$ material. The activity of ALT and AST in the control group of rats was $(48.4 \pm 3.5)$ and $(167.2 \pm 7.8) \mathrm{U} / 1$ $(n=7)$, respectively. Chronic (30 and 100 days) oral introduction of $\mathrm{TiO}_{2}$ suspension caused a significant increase in the activity indices for these enzymes: in case of rats, receiving nano- $\mathrm{TiO}_{2}$ suspension for 30 days, ALT increased more than 6 -fold, and the activity of AST increased 2.5 times on average the control. The prolonged effect of nano- $\mathrm{TiO}_{2}$ up to 100 days was characterized with the following changes inactivity: ALT indices were still increasing, reaching the 7-fold increase compared to the control, whereas AST activity was slowing down to some degree, on average amounting to $201.4 \%$ compared to the control (in all cases $P<0.001, n=6$ ) (Fig. 1). A significant increase in the activity of ALT and AST indicated the process of hepatocyte lysis - one of the main pathological syndromes of liver damage. However, a significant excess in the activity of these enzymes may be also related to the activation of muscle tissue destruction processes under chronic effect of $\mathrm{TiO}_{2}$ nanoparticles [22].

Aminotransferases, represented by ALT (EC 2.6.1.2) and AST (EC 2.6.1.1), transfer aminogroups from 2-aminoacid to 2-oxoacid involving pyridoxal phosphate as a cofactor. Enhanced activity of these enzymes in blood plasma indicates the 


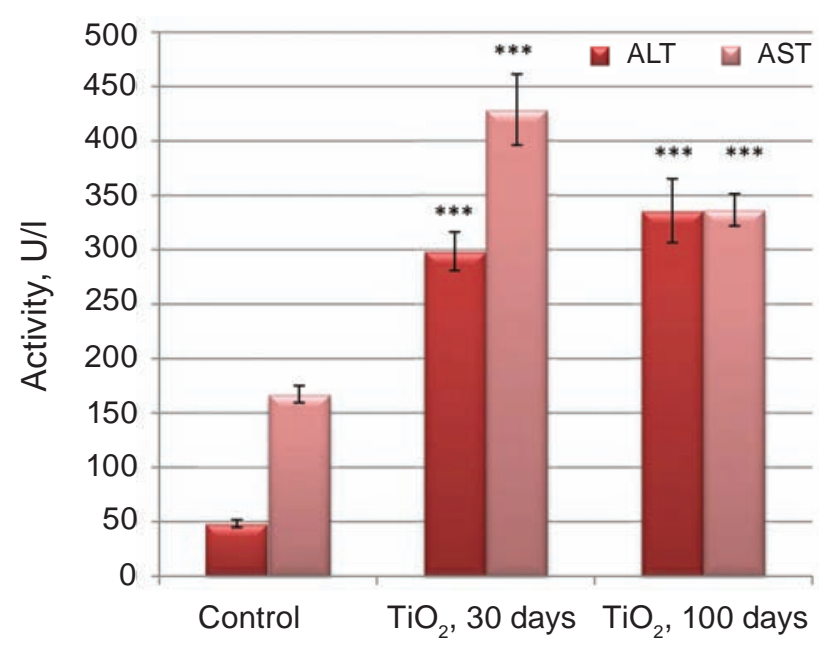

Fig. 1. The indices of enzymatic activity of alanine aminotransferase (ALT) and aspartate aminotransferase (AST) in blood plasma of rats in the control $(n=7)$ and under the chronic effect of nanosized $\mathrm{TiO}_{2}$ material in vivo (average size of $21 \mathrm{~nm}$, the ratio of polymorphs - rutile: anatase $=1: 4)$ for 30 and 100 days $(n=6) ; * * * P<0.001$ regarding the control

damage of plasma and/or mitochondrial membranes. Thus, enhanced activity of AST is a marker of damaged tissues of liver, kidney, heart and/or skeletal muscles as well as erythrocytes; in a similar way, enhanced activity of ALT accompanies the destruction of these tissues [23]. Although hepatocytes contain AST in a relatively higher amount, enhanced relative activity of ALT in blood plasma is a marker of damaged liver tissue.

Thus, detecting the hepatotoxic effect of $\mathrm{TiO}_{2}$ involved determining the dynamic pattern for De Ritis ratio (the ratio of AST/ALT activities) in blood plasma of rats in the control group and animals, burdened with nanomaterial. There was a reliable timedependent decrease in this ratio, which amounted to 3.45 for the control, whereas under the effect of $\mathrm{TiO}_{2}$ for 30 days it was 1.44 and for 100 days - about 1 . Therefore, as the deviation of De Ritis ratio was observed towards decreasing, it proved the hepatotoxic effect of nano- $\mathrm{TiO}_{2}$ [24-26].

We have also studied one of the main indices of pigment exchange - bilirubin of blood, which is a highly informative parameter of the functional state of liver. The concentration of bilirubin in blood plasma of control rats was as follows: direct $(2.84 \pm 0.17) \mu \mathrm{M}$, total $-(8.96 \pm 0.53) \mu \mathrm{M}$ and indirect $-(6.12 \pm 0.32) \mu \mathrm{M}(n=7)$. In case of rats, oral administered nano- $\mathrm{TiO}_{2}$ for 30 days, there was

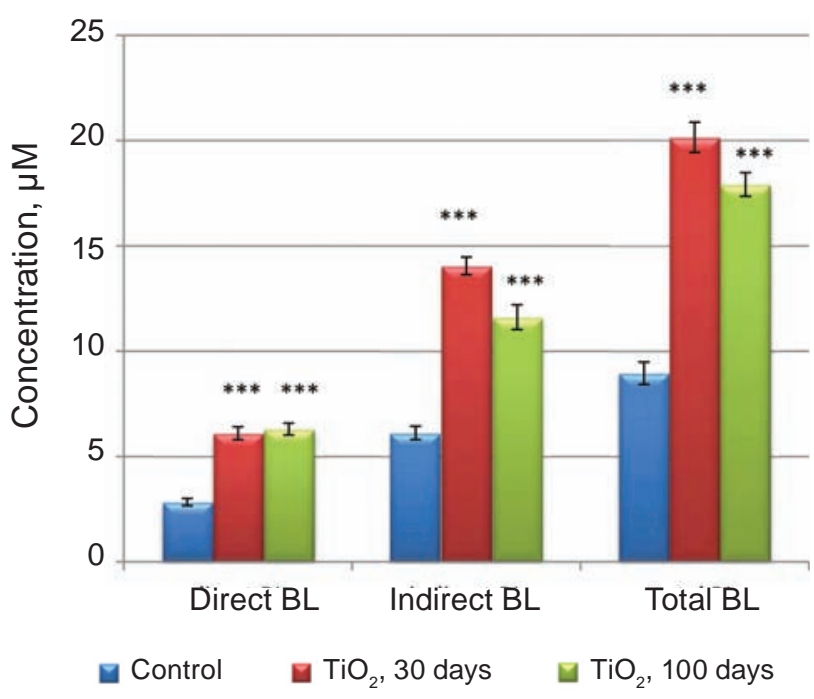

Fig. 2. The concentrations of direct, indirect and total bilirubin (BL) in blood plasma of rats in control $(n=7)$ and under chronic effect of nano-TiO in vivo (average size of $21 \mathrm{~nm}$, the ratio of polymorphs rutile: anatase $=1: 4)$ for 30 and 100 days $(n=6)$; $* * * P<0.001$ regarding the control

an observed reliable increase in bilirubin concentration, which was as follows: direct $-(6.11 \pm 0.31)$ $\mu \mathrm{M}$, bound $-(20.16 \pm 0.72) \mu \mathrm{M}$ and indirect $(14.05 \pm 0.42) \mu \mathrm{M}$ (in all cases $P<0.001$ regarding the control group, $n=6$ ). Bilirubin concentration in the plasma of rats, burdened with $\mathrm{TiO}_{2}$ for 100 days, was as follows: direct $-(6.30 \pm 0.28) \mu \mathrm{M}$, total $(17.92 \pm 0.56)$ and indirect $-(11.62 \pm 0.59) \mu \mathrm{M}$ (in all cases $P<0.001$ regarding the control group, $n=6$ ) (Fig. 2). Therefore, the indices of bilirubin concentration remained at a higher level under the exposure to $\mathrm{TiO}_{2}$, which indicated hepatotoxicity of this nanomaterial, but no time dependence was observed. A significant increase in bilirubin concentration in blood plasma demonstrated a considerable destruction of liver parenchyma which allowed bilirubin to penetrate blood [24, 27].

We have also made thymol test in control and under chronic exposure of rats to $\mathrm{TiO}_{2}$. A significant increase in thymol test was observed: in control $(0.95 \pm 0.12)$ rel.un., under the effect of $\mathrm{TiO}_{2}$ for 30 days $(2.94 \pm 0.31)$ rel.un. and under the effect of $\mathrm{TiO}_{2}$ for 100 days $(3.01 \pm 0.29)$ rel.un. Thymol test is a marker of mesenchymal inflammatory process in the liver, and its results are determined by the ratio between the content of $\beta$ - and $\gamma$-globulins and albumin in blood plasma. Thus, our results demonstrate that nano- $\mathrm{TiO}_{2}$ has considerable hepatotoxicity and under 
chronic effect causes the impairment of protein and pigment exchange in the liver.

The concentration of bile acids in blood plasma of rats under chronic exposure to nano-TiO ${ }_{2}$. Along with the indices of enzymatic activity of ALT and AST, a sensitive index of impaired liver functioning is the level of bile acids in blood plasma [23, 24]. Thus, as our previous studies detected significant changes in protein and pigment exchange in liver tissue of rats under chronic intragastric burden of the organism with nano-TiO ${ }_{2}$ in vivo, the following series of experiments was targeted at analyzing the exchange of bile acids in the organism of rats, burdened with $\mathrm{TiO}_{2}$ for 30 days.

Using extraction methods (with the mixture of ethanol:acetone $=1: 3$ ) and separation with liquid thin-layer chromatography (in the mixture of amyl acetic ester:toluene:butanol:water=3:1:1:3:1), we have studied the composition of conjugated (TCA - taurocholic acid, the mixture of TCDCA - taurochenodeoxycholic acid and TDCA - taurodeoxycholic acid, GCA - glycocholic acid, the mixture of GCDCA glycochenodeoxycholic acid and GDCA - glycodeoxycholic acid) and free (CA - cholic acid and the mixture of CDCA - chenodeoxycholic and DCA deoxycholic) bile acids in blood plasma of animals. It was determined that mass concentrations of all the mentioned bile acids undergo reliable changes compared against the control (Fig. 3), with a significant increase in the content of free cholic acid only (from $23.0 \pm 1.4 \mathrm{mg} \%$ to $30.8 \pm 1.8 \mathrm{mg} \%, n=6, P<0.05$ ), whereas the concentrations of other free and conjugated biliary acids decrease by $30-50 \%$ on average. In particular, the content of the mixture of GCDCA and GDCA in blood plasma of rats decreased under chronic effect of $\mathrm{TiO}_{2}$ from $29.0 \pm 1.8 \mathrm{mg} \%$ (in control) to $15.5 \pm 0.9 \mathrm{mg} \%(n=6, P<0.05)$; in case of conjugated glycocholic acid, there was an observed decrease in its concentration from $149.9 \pm 4.3 \mathrm{mg} \%$ to $96.8 \pm 5.5 \mathrm{mg} \%(n=6, P<0.05)$. The concentration of taurocholic acid decreased from $195.0 \pm 6.7 \mathrm{mg} \%$ (in control) to $137.6 \pm 4.6 \mathrm{mg} \%(n=6, P<0.05)$. In case of the mixture of free biliary acids CDCA and DCA, there was an observed decrease in their concentrations in blood plasma of rats under chronic effect of $\mathrm{TiO}_{2}$ from $9.5 \pm 0.3 \mathrm{mg} \%$ to $5.5 \pm 0.7 \mathrm{mg} \%$ ( $n=6, P<0.05$ ). The most significant decrease was remarkable for the mixture of conjugated bile acids TCDCA and TDCA: from $94.2 \pm 3.2 \mathrm{mg} \%$ in control to $47.6 \pm 2.7 \mathrm{mg} \%$ under the effect of $\mathrm{TiO}_{2}(n=6$, $P<0.05)$.
Nanoparticles of metaloxides, in particular, $\mathrm{TiO}_{2}$, are capable of penetrating the tissues of the organism and accumulating therein. The methods of mass-spectrometry, electronic microscopy and radioisotope assay $[8,28,29]$ demonstrated that liver was one of the organs, depositing a considerable amount of nano- $\mathrm{TiO}_{2}$. At the sometime, numerous studies using laboratory animals indicate that in vivo the burdening of the organism with nano-TiO ${ }_{2}$ is accompanied with inflammatory reactions and size-, polymorph- and time-dependent disruptions in the functioning of internal organs (including liver, kidneys, spleen, heart muscle and reproductive glands) $[28,30-32]$. For instance, according to the data of E. Abbasi-Oshaghi et al. [33], the application of $\mathrm{TiO}_{2}$ in the concentrations of $10-100 \mathrm{mg} / \mathrm{kg}$ for 30 days conditioned a considerable increase in the activity of ALT and AST and in the concentration of total bilirubinin blood plasma of rats, and these effects were accompanied with a considerable inhibition of the expression of antioxidant protection genes (superoxide dismutase, glutathione peroxidase, catalase) and enhanced expression of proapoptotic genes (Bax and p53) and decreased expression of antiapoptotic genes (Bcl2) in liver tissue; the effect of effector caspases in the homogenate of hepatocytes also increased considerably. Similar hepatotoxic and genotoxic effects were also observed by the group of Jia X.et al. [34] after intragastric administration of $5-50 \mathrm{mg} / \mathrm{kg}$ of nano- $\mathrm{TiO}_{2}$ to mice for 14 days. The studies of Yang J. et al. [28] using the simulation of intragastric burdening mice with high concentrations of nano- $\mathrm{TiO}_{2}(5-150 \mathrm{mg} / \mathrm{kg} /$ day for 14 days) demonstrated that the initial marker of toxic damage to liver by nanomaterials is bilirubin: the concentration of the latter in blood plasma was increased in a dose-dependent manner at the background of changes in enzymatic activity of ALT and AST; the increase in bilirubin concentration correlated with a considerable increase in the expression levels of transporter genes Oatp1 and Mrp3, and enzymes Cyp2b10 and Cyp2c37. The results, obtained by us (the increase in the activity of ALT and AST, the change in De Ritis index, increased level of bilirubin), demonstrate that subchronic intake of non-high concentrations of nano- $\mathrm{TiO}_{2}$ in the organism is accompanied with the accumulation of this nanomaterial in the liver tissue and conditions considerable changes in its functioning. The result of thymol test also demonstrates disrupted metabolism in the liver tissue of rats at the effect of nano- $\mathrm{TiO}_{2}[35]$. 
As mentioned above, nanoparticles of $\mathrm{TiO}_{2}$ condition expressed genotoxic effects (oxidative damage and breaks in DNA molecules, induced apoptosis), and also change gene expression profiles in liver cells, here the changes are related to genes of antioxidant protection and apoptosis as well as metabolic genes [28, 36, 37]. For instance, Yang J. et al. [28] determined that burdening the organism of mice with nano- $\mathrm{TiO}_{2}$ is accompanied with disrupted expression of genes, encodings specific enzymes of P450 superfamily; these enzymes are known to ensure the metabolism of bilirubin and bile acids [38]. One of the central links of the toxic effect of $\mathrm{TiO}_{2}$ on cells is disrupted functioning of mitochondria [39]. The changes, obtained by using the level of some bile acids in blood plasma of rats, burdened with nano- $\mathrm{TiO}_{2}$, may be related to nanoparticle-induced changes in the level of enzymes, ensuring synthesis and transformation of bile acids, in liver.

Thus, in our studies, $\mathrm{TiO}_{2}$ mostly (except for CA) caused a significant inhibition of biosynthesis of both free and glycine-conjugated trihydroxycholane acids, the synthesis of which is closely related to the activity of enzymes of microsomal oxidation in a neutral way [23]. Similarly, this nanomaterial induced the inhibition of conjugation processes between bile acids and taurine. As the synthesis of the primary chenodeoxycholic acid by hepatocytes occurs with active involvement of mitochondria enzymes, the decrease in the level of the mixture $[C D C A+D C A]$ in blood plasma demonstrates that one of the primary mechanisms of impairing pigment exchange in the liver tissue is inhibiting the mitochondrial function of hepatocytes $[8,23]$.

The activity of ATPs of rat erythrocyte plasma membranes under the chronic effect of nano- $\mathrm{TiO}_{2}$. Membrane proteins with ATP activity maintain the transmembrane difference in the concentration of ions $\mathrm{Na}^{+}, \mathrm{K}^{+}$and $\mathrm{Ca}^{2+}$. These systems of primary ion transport of plasma membrane include $\mathrm{Na}^{+}, \mathrm{K}^{+}-$ ATPase (pumps $2 \mathrm{~K}^{+}$ions into the cell per one catalytic action and pumps out $3 \mathrm{Na}^{+}$ions) and $\mathrm{Ca}^{2+}-$ pump (ensures the extrusion of $\mathrm{Ca}^{2+}$ ions into the extracellular space). The impairment of the transport

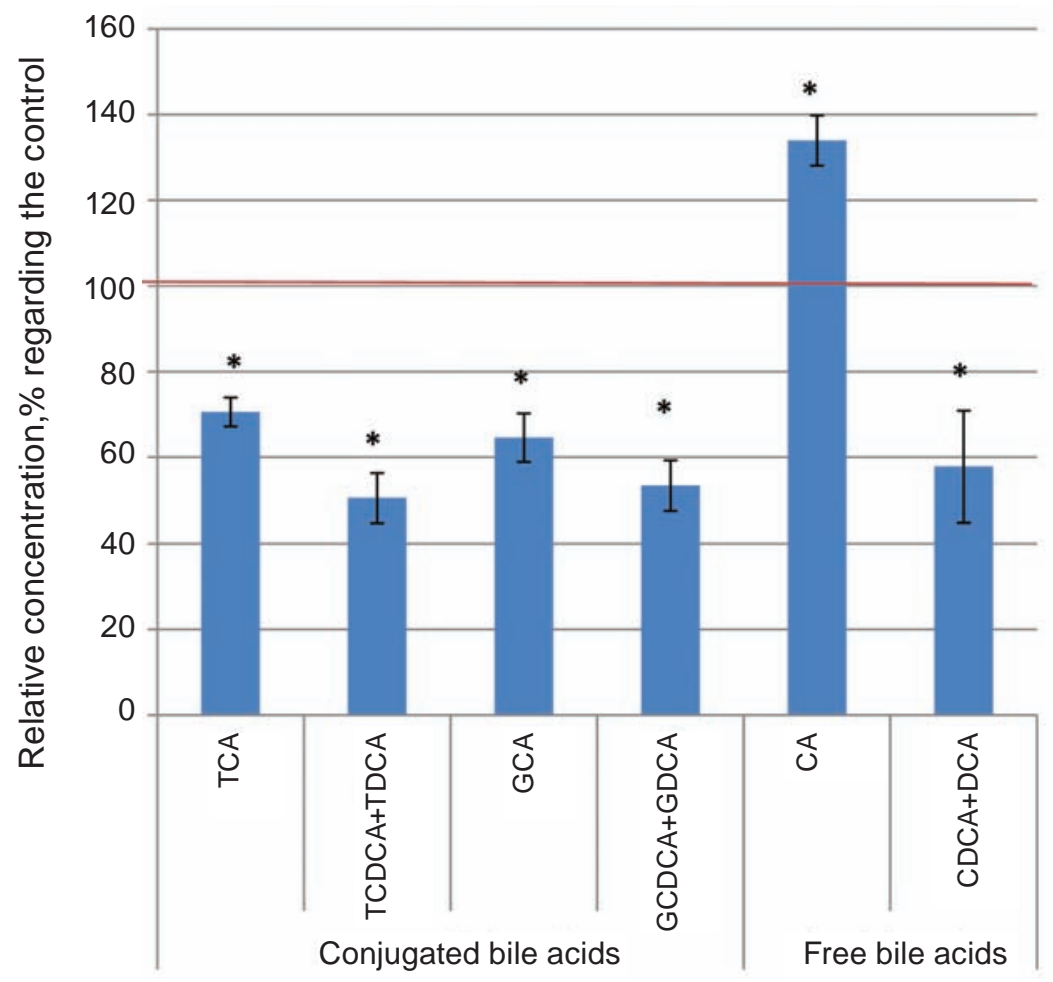

Fig. 3. The relative concentration (in \% regarding the corresponding control values) of conjugated and free bile acids in blood plasma of rats, burdened with nanosize $\mathrm{TiO}_{2}$ material (average size of $21 \mathrm{~nm}$, the ratio of polymorphs - rutile: anatase $=1: 4)$ for 30 days $(n=6)$. Legends: TCA - taurocholic acid, TCDCA - taurochenodeoxycholic acid, TDCA - taurodeoxycholic acid, GCA - glycocholic acid, GCDCA - glycochenodeoxycholic acid, GDCA - glycodeoxycholic acid, CA - cholic acid, CDCA - chenodeoxycholic acid, DCA deoxycholic acid; $* P<0.05$ regarding the control 


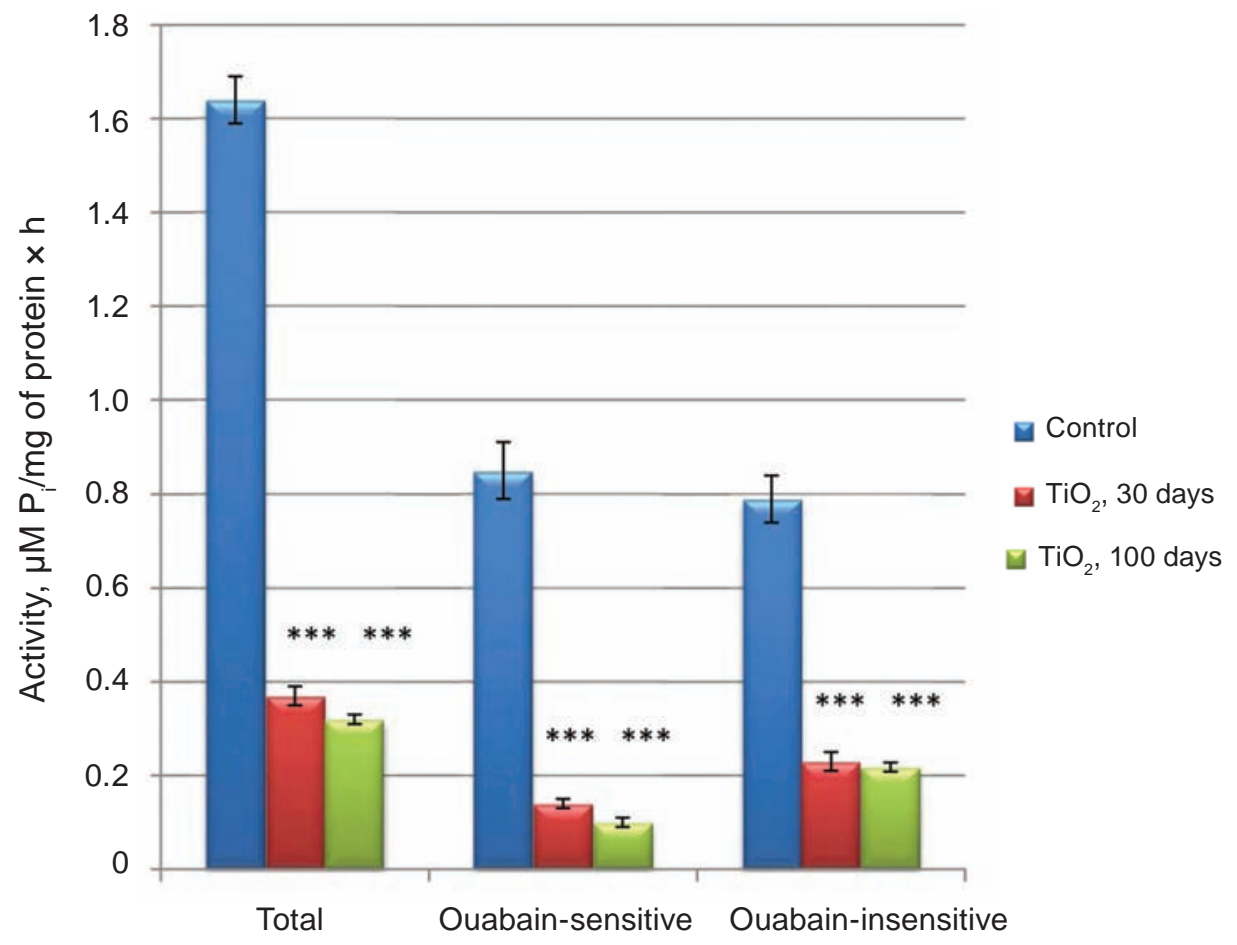

Fig. 4 The enzymatic activity of total, ouabain-sensitive $\left(\mathrm{Na}^{+}, \mathrm{K}^{+}\right.$-ATPase) and ouabain-insensitive ATPases in control and under the chronic effect of nanosize $\mathrm{TiO}_{2}$ material in vivo (average size of $21 \mathrm{~nm}$, the ratio of polymorphs - rutile: anatase $=1: 4)$ for 30 and 100 days $(n=6) ; * * * P<0.001$ regarding the control

function of active ionic transport systems may cause different effects, including apoptosis or mixed processes of cell death [27].

In the control the indices of total $\mathrm{Mg}^{2+}$ dependent, ouabain-sensitive, and ouabain-insensitive ATPase activity were as follows: $(1.64 \pm 0.05)$ $\mathrm{mg} \mathrm{P}_{\mathrm{i}} / \mathrm{mg}$ of protein $\mathrm{h},(0.85 \pm 0.06) \mathrm{mg} \mathrm{P}_{\mathrm{i}} / \mathrm{mg}$ of protein $\mathrm{h}$ and $(0.79 \pm 0.05) \mathrm{mg} \mathrm{P}_{\mathrm{i}} / \mathrm{mg}$ of protein $\mathrm{h}$; therefore, the activity of $\mathrm{Na}^{+}, \mathrm{K}^{+}$-ATPase for rat erythrocyte plasma membrane was $51.8 \%$ on average compared against the total ATPase activity, which served as $100 \%$. Under chronic exposure (for 30 and 100 days) to nanosize $\mathrm{TiO}_{2}$ material, the activity of enzymes of the primary active ionic transport decreased considerably compared against the data for the control group. For instance, for the group of 30 days of exposure to $\mathrm{TiO}_{2}$, the indices of total $\mathrm{Mg}^{2+}$ dependent, ouabain-dependent, ouabain-sensitive and ouabain-insensitive ATPase activity respectively were as follows: $(0.37 \pm 0.02) \mathrm{mg} \mathrm{P}_{\mathrm{i}} / \mathrm{mg}$ of protein $\mathrm{h}$, $(0.14 \pm 0.01) \mathrm{mg} \mathrm{P}_{\mathrm{i}} / \mathrm{mg}$ of protein $\mathrm{h}$ and $(0.23 \pm 0.02)$ $\mathrm{mg} \mathrm{P}_{\mathrm{i}} / \mathrm{mg}$ of protein.h $(n=6)$. In the group of 100 days of exposure to $\mathrm{TiO}_{2}$ we observed further decrease in the activity of total $\mathrm{Mg}^{2+}$-dependent, ouabain-sensitive and ouabain-insensitive ATPases, the values of which were as follows: $(0.32 \pm 0.01) \mathrm{mg} \mathrm{P}_{\mathrm{i}} /$ $\mathrm{mg}$ of protein $\cdot \mathrm{h},(0.10 \pm 0.01) \mathrm{mg} \mathrm{P}_{\mathrm{i}} / \mathrm{mg}$ of protein $\mathrm{h}$ and $(0.22 \pm 0.01) \mathrm{mg} \mathrm{P}_{\mathrm{i}} / \mathrm{mg}$ of protein $\mathrm{h}(n=6)$. Analyzing these data, it is noteworthy that there was also a decrease in the relative contribution of $\mathrm{Na}^{+}, \mathrm{K}^{+}$-ATPase into the total $\mathrm{Mg}^{2+}$-dependent ATPase activity of erythrocyte plasma membranes under the effect of $\mathrm{TiO}_{2}$ in vivo: in the group of animals, treated for 30 days, these parameters were $38.0 \%$ on average, and in the group of animals, treated for 100 days $-31.6 \%$ on average (Fig. 4).

Simulated studies of long-term burdening of the organism with nano- $\mathrm{TiO}_{2}$ demonstrate that the disruption of cell metabolism, induced by these nanoparticles, is accompanied with considerable inhibition of the effect of both intracellular enzymes and transmembrane systems of active ion transport. For instance, Hong F. et al. determined the inhibition of $\mathrm{Na}^{+}, \mathrm{K}^{+}$-ATPase, $\mathrm{Ca}^{2+}$-ATPase and $\mathrm{Ca}^{2+}, \mathrm{Mg}^{2+}$-ATPase of plasmatic spermatozoa membranes of rats, which were oral administered the suspension of nanosize $\mathrm{TiO}_{2}$ for 60 days [40]. Similar results were obtained for neurons of the central nervous system and cardiomyocytes of mice, these effects were accompanied with the disruption of ion concentration in the tissues [41, 42]. The systems of primary ion transport create the driving force for transmembrane transport 
of substances, in particular, in the liver tissue the gradient of ions $\mathrm{Na}^{+}$, which forms $\mathrm{Na}^{+}, \mathrm{K}^{+}$-ATPase, is the prerequisite of transporting biliary acids and bile secretion [43]. Therefore, when the organism was burdened with nanosize $\mathrm{TiO}_{2}$ material in vivo, there was observed impairment of transmembrane balance of ions $\mathrm{Na}^{+}$and $\mathrm{K}^{+}$, and probably even $\mathrm{Ca}^{2+}$. It can also be predicted, it is not possible to assume that the impairment of ion-transporting processes in plasma membrane is one of the factors of the toxic effect of titanium dioxide.

The functional state of liver and enzymatic activity of the preparations of rat erythrocyte plasma membranes under chronic effect (for 30 and 100 days) of nanosize titanium dioxide material in vivo (average size of $21 \mathrm{~nm}$, the ratio of polymorphs - rutile: anatase $=1: 4$ ) was studied in this work. It was established that burdening the organism with $\mathrm{TiO}_{2}$ caused a significant increase in the activity of enzymes of alanine aminotransferase and aspartate aminotransferase in blood plasma along with the decrease in the ratio of their activities (De Ritis ratio), which generally proved the destruction of hepatocytes in the presence of $\mathrm{TiO}_{2}$ in the organism.

It was demonstrated that under the chronic effect (for 30 and 100 days) of nanosize $\mathrm{TiO}_{2}$ material in vivo, there was a significant increase in the concentrations of direct, indirect and bound bilirubin in blood plasma of rats, which proved $\mathrm{TiO}_{2}$-induced impairment of pigment exchange in the liver tissue.

It was found that under chronic effect (for 30 days) of nano- $\mathrm{TiO}_{2}$ in vivo, there was an observed decrease in the concentrations of conjugated (taurocholic, taurochenodeoxycholic, taurodeoxycholic, glycocholic, glycochenodeoxycholic, and glycodeoxycholic) and free (glycodeoxycholic and deoxycholic) bile acids in blood plasma of rats, whereas the concentration of free cholic acid increased; the mentioned results demonstrated significant impairment of pigment exchange in the liver of rats.

It was established that under the chronic effect (for 30 and 100 days) of nano- $\mathrm{TiO}_{2}$ in vivo there was observed significant inhibition of functioning of the enzymes of primary active ionic transport (total $\mathrm{Mg}^{2+}$-dependent, ouabain-sensitive $\mathrm{Na}^{+}, \mathrm{K}^{+}$-ATPase and ouabain-insensitive) ATPase activities of erythrocyte plasma membranes; these results prove the impairment of transplasmalema ion-transporting processes and ionic homeostasis in cells.

Conflict of interest. Authors have completed the Unified Conflicts of Interest form at http://ukrbiochemjournal.org/wp-content/uploads/2018/12/ coi_disclosure.pdf and declare no conflict of interest.

This research was supported by the Ministry of Education and Science of Ukraine grant (registration number 19БФ07-01).

\section{ГЕПАТОТОКСИЧНІСТЬ $\mathrm{TiO}_{2} 3 \mathrm{~A}$ ТРИВАЛОГО ВВЕДЕННЯ ЩУРАМ}

\author{
О. В. Цимбалюк, С. П. Весельський, \\ А. М. Науменко, Т. Л. Давидовська, \\ I. C. Войтешенко, I. I. Чиж, \\ В. А. Скришевський
}

Інститут високих технологій, Київський національний університет імені Тараса Шевченка; e-mail: otsymbal@bigmir.net

Порошок діоксиду титану $\left(\mathrm{TiO}_{2}\right)$, який використовується як білий барвник, довгий час вважався інертним матеріалом, незважаючи на накопичення його в тканинах печінки після проникнення в організм. Метою дослідження було оцінити біохімічні маркери функціонування печінки у плазмі крові та активність АТРази плазматичної мембрани еритроцитів за перорального введення суспензії наночастинок $\mathrm{TiO}_{2}(0,1 \mathrm{мг/}$ кг щодня) щурам Wistar протягом 30 та 100 днів. Показано значне підвищення активності аланінамінотрансферази та аспартатамінотрансферази, а також вмісту прямого, непрямого та зв'язаного білірубіну. Також встановлено вірогідне зменшення кон'югованих (таурохолевої, таурохенодезоксихолевої, тауродезоксихолевої, глікохолевої, глікохенодезоксихолевої та глікодезоксихолевої) і вільних (глікодезоксихолевої і дезоксихолевої) жовчних кислот у разі супутнього збільшення концентрації вільної холевої кислоти в плазмі крові щурів під час введення $\mathrm{TiO}_{2}$, що вказувало на значне порушення пігментного обміну в печінці щурів. Під час введення $\mathrm{TiO}_{2}$ спостерігалося значне пригнічення еритроцитарної плазматичної мембрани $\mathrm{Mg}^{2+}$-залежної, уабаїнчутливої $\mathrm{Na}^{+}, \mathrm{K}^{+}$-АТРази та уабаїннечутливої АТРази. Ці результати передбачають порушення процесів транспорту трансплазмалеми іонів та іонного гомеостазу клітин, індукований $\mathrm{TiO}_{2}$.

К л ю чов і слов а: наночастинки $\mathrm{TiO}_{2}$, аланінамінотрансфераза, аспартатамінотрансфераза, білірубін, жовчні кислоти, АТРазна активність плазматичних мембран. 


\section{References}

1. Song Y, Chen S. Janus nanoparticles: preparation, characterization, and applications. Chem Asian J. 2014; 9(2): 418-430.

2. Trovato MC, Andronico D, Sciacchitano S, Ruggeri RM, Picerno I, Di Pietro A, Visalli G. Nanostructures: between natural environment and medical practice. Rev Environ Health. 2018; 33(3): 305-317.

3. Proquin $\mathrm{H}$, Jetten $\mathrm{MJ}$, Jonkhout MCM, Garduño-Balderas LG, Briedé JJ, de Kok TM, van Loveren H, Chirino YI. Transcriptomics analysis reveals new insights in E171-induced molecular alterations in a mouse model of colon cancer. Sci Rep. 2018; 8(1): 9738.

4. $\mathrm{Xu}$ F. Review of analytical studies on $\mathrm{TiO}_{2}$ nanoparticles and particle aggregation, coagulation, flocculation, sedimentation, stabilization. Chemosphere. 2018; 212: 662-677.

5. Weir A, Westerhoff P, Fabricius L, Hristovski K, von Goetz N. Titanium dioxide nanoparticles in food and personal care products. Environ Sci Technol. 2012; 46(4): 2242-2250.

6. De Matteis V, Cascione M, Brunetti V, Toma CC, Rinaldi R. Toxicity assessment of anatase and rutile titanium dioxide nanoparticles: The role of degradation in different $\mathrm{pH}$ conditions and light exposure. Toxicol In Vitro. 2016; 37: 201-210.

7. Bettini S, Boutet-Robinet E, Cartier C, Coméra C, Gaultier E, Dupuy J, Naud N, Taché S, Grysan P, Reguer S, Thieriet N, Réfrégiers M, Thiaudière D, Cravedi JP, Carrière M, Audinot JN, Pierre FH, Guzylack-Piriou L, Houdeau E. Food-grade $\mathrm{TiO}_{2}$ impairs intestinal and systemic immune homeostasis, initiates preneoplastic lesions and promotes aberrant crypt development in the rat colon. Sci Rep. 2017; 7: 40373.

8. Tsymbalyuk OV, Naumenko AM, Rohovtsov OO, Skoryk MA, Voiteshenko IS, Skryshevsky VA, Davydovska TL. Titanium dioxide modulation of the contractibility of visceral smooth muscles in vivo. Nanoscale Res Lett. 2017; 12(1): 129.

9. Tsymbalyuk OV, Naumenko AM, Skoryk MA, Nyporko AY, Davidovska TL, Skryshevsky VA. Histamine- and nicotine-stimulated modulations of mechanic activity of smooth muscles in gastrointestinal tract at the impact of nanosized $\mathrm{TiO}_{2}$ material. Biopolym Cell. 2016; 32(2): 140149.

10. Naumenko AM, Dmytrenko OV, Shapoval LM, Tsymbalyuk OV, Sagach VF, Davydovska TL.
Effects of injections of nanostructured titanium dioxide into the rat medullary nuclei involved in cardiovascular control. Neurophysiology. 2018; 50(6): 409-414.

11. Khalili Fard J, Jafari S, Eghbal MA. A review of molecular mechanisms involved in toxicity of nanoparticles. Adv Pharm Bull. 2015; 5(4): 447454.

12. Adverse Effects of Engineered Nanomaterials: Exposure, Toxicology, and impact on human health. Second Edition / Edited by Fadeel B., Pietroiusti A., Shvedova A.A. Elsevier, Academic Press, 2017, 468 p.

13. Geraets L, Oomen AG, Krystek P, Jacobsen NR, Wallin $\mathrm{H}$, Laurentie $\mathrm{M}$, Verharen HW, Brandon EFA, de Jong WH. Tissue distribution and elimination after oral and intravenous administration of different titanium dioxide nanoparticles in rats. Part Fibre Toxicol. 2014; 11: 30.

14. Abbasi-Oshaghi E, Mirzaei F, Pourjafar M. NLRP3 inflammasome, oxidative stress, and apoptosis induced in the intestine and liver of rats treated with titanium dioxide nanoparticles: in vivo and in vitro study. Int $J$ Nanomedicine. 2019; 14: 1919-1936.

15. Reitman S, Frankel S. A colorimetric method for the determination of serum glutamic oxalacetic and glutamic pyruvic transaminases. Am J Clin Pathol. 1957; 28(1): 56-63.

16. Jendrassik L, Grof P. Colorimetric Method of Determination of bilirubin. Biochem Z. 1938; 297: 81-82.

17. Cohen PP, Thompson FL. Mechanism of the thymol turbidity test. J Lab Clin Med. 1947; 32(5): 475-480.

18. A. c. No 441106614 USSR MTIS 01W33/50 Veselsky SP, Lyashchenko PS, Lukyanenko IA. A method for determining bile acids in biological fluids. USSR No. 1624322 declared 25.01.1988, published 30.01.1991, Bull. N 4. (In Russian).

19. Lowry OH, Rosebrough NJ, Farr AL, Randall RJ. Protein measurement with the Folin phenol reagent. J Biol Chem. 1951; 193(1): 265-275.

20. Tsymbalyuk OV, Kosterin SO, Rodik RV, Kalchenko VI. Comparative study in vitro and in vivo of the effects of calixarene $\mathrm{C} 107$ and oubaine on $\mathrm{Na}^{+}, \mathrm{K}^{+}$-ATPase activity in the plasma membranes of rat hepatocytes. Ukr Biokhim Zhurn. 2010; 82(4): 78-85. (In Ukrainian).

21. Rathbun WB, Betlach MV. Estimation of enzymatically produced orthophosphate in the 
presence of cysteine and adenosine triphosphate. Anal Biochem. 1969; 28(1): 436-445.

22. Hong J, Zhang Yu-Q. Murine liver damage caused by exposure to nano-titanium dioxide. Nanotechnology. 2016; 27(11): 112001.

23. Hofmann AF, Hagey LR. Bile acids: chemistry, pathochemistry, biology, pathobiology and therapeutics. Cell Mol Life Sci. 2008; 65(16): 2461-2483.

24. Hoffmann WE, Solter PhF. Clinical Biochemistry of Domestic Animals (Sixth Edition), Chapter 12 - Diagnostic Enzymology of Domestic Animals. Academic Press, 2008, P. 351-378.

25. De Ritis F, Giusti G, Piccinino F, Cacciatore L. Biochemical laboratory tests in viral hepatitis and other hepatic diseases. Evaluation and follow-up. Bull World Health Organ. 1965; 32(1): 59-72.

26. Botros M, Sikaris KA. The de Ritis ratio: the test of time. Clin Biochem Rev. 2013; 34(3): 117-130.

27. Tsymbaliuk OV, Kosterin SO. $\mathrm{Na}^{+}, \mathrm{K}_{+}$-ATPase, endogenous cardiotonic steroids and their transducing role. Ukr Biokhim Zhurn. 2012; 84(1): 5-17. (In Ukrainian).

28. Yang J, Luo M, Tan Z, Dai M, Xie M, Lin J, Hua H, Ma Q, Zhao J, Liu A. Oral administration of nano-titanium dioxide particle disrupts hepatic metabolic functions in a mouse model. Environ Toxicol Pharmacol. 2017; 49: 112-118.

29. Kreyling WG, Holzwarth U, Schleh C, Kozempel J, Wenk A, Haberl N, Hirn S, Schäffler M, Lipka J, Semmler-Behnke M, Gibson N. Quantitative biokinetics of titanium dioxide nanoparticles after oral application in rats: Part 2. Nanotoxicology. 2017; 11(4): 443453.

30. Hong F, Yu X, Wu N, Zhang YQ. Progress of in vivo studies on the systemic toxicities induced by titanium dioxide nanoparticles. Toxicol Res. (Camb). 2017; 6(2): 115-133.

31. Mohammadpour R, Dobrovolskaia MA, Cheney DL, Greish KF, Ghandehari H. Subchronic and chronic toxicity evaluation of inorganic nanoparticles for delivery applications. Adv Drug Deliv Rev. 2019; 144: 112-132.

32. Shi H, Magaye R, Castranova V, Zhao J. Titanium dioxide nanoparticles: a review of current toxicological data. Part Fibre Toxicol. 2013; 10: 15.

33. Shakeel M, Jabeen F, Qureshi NA, Fakhr-EAlam M. Toxic effects of titanium dioxide Nanoparticles and titanium dioxide bulk salt in the liver and blood of male sprague-dawley rats assessed by different assays. Biol Trace Elem Res. 2016; 173(2): 405-426.

34. Jia X, Wang S, Zhou L, Sun L. The potential liver, brain, and embryo toxicity of titanium dioxide nanoparticles on mice. Nanoscale Res Lett. 2017; 12(1): 478.

35. Słomka M, Szczerbo-Trojanowska M, Celiński K, Skrzydło-Radomańska B. [Evaluation of the consequences of hepatic artery embolization under experimental conditions. Ann Univ Mariae Curie Sklodowska Med. 1991; 46: 81-87.

36. Li Y, Yan J, Ding W, Chen Y, Pack LM, Chen T. Genotoxicity and gene expression analyses of liver and lung tissues of mice treated with titanium dioxide nanoparticles. Mutagenesis. 2017; 32(1): 33-46.

37. Chen T, Yan J, Li Y. Genotoxicity of titanium dioxide nanoparticles. J Food Drug Anal. 2014; 22(1): 95-104.

38. Shalan H, Kato M, Cheruzel L. Keeping the spotlight on cytochrome P450. Biochim Biophys Acta Proteins Proteom. 2018; 1866(1): 80-87.

39. Natarajan V, Wilson CL, Hayward SL, Kidambi S. Titanium dioxide nanoparticles trigger loss of function and perturbation of mitochondrial dynamics in primary hepatocytes. PLoS One. 2015; 10(8): e0134541.

40. Hong F, Si W, Zhao X, Wang L, Zhou Y, Chen M, Ge Y, Zhang Q, Wang Y, Zhang J. $\mathrm{TiO}_{2}$ nanoparticle exposure decreases spermatogenesis via biochemical dysfunctions in the testis of male mice. J Agric Food Chem. 2015; 63(31): 7084-7092.

41. $\mathrm{Hu} \mathrm{R}$, Gong $\mathrm{X}$, Duan $\mathrm{Y}$, Li N, Che Y, Cui Y, Zhou M, Liu C, Wang H, Hong F. Neurotoxicological effects and the impairment of spatial recognition memory in mice caused by exposure to $\mathrm{TiO}_{2}$ nanoparticles. Biomaterials. 2010; 31(31): 8043-8050.

42. Yu X, Hong F, Zhang YQ. Cardiac inflammation involving in $\mathrm{PKC} \varepsilon$ or ERK1/2-activated NF- $\mathrm{KB}$ signalling pathway in mice following exposure to titanium dioxide nanoparticles. J Hazard Mater. 2016; 313: 68-77.

43. Garduño-Siciliano L, Labarrios F, Tamariz J, Moreno MG, Chamorro G, Muriel P. Effect of alpha-asarone and a derivative on lipids, bile flow and $\mathrm{Na}^{+} / \mathrm{K}^{+}$-ATPase in ethinyl estradiolinduced cholestasis in the rat. Fundam Clin Pharmacol. 2007; 21(1): 81-88. 